\title{
Relationship Background to the Economic Family Student Learning Results Elementary School 2 Peukan Pidie
}

\author{
$\underline{\text { Ismail }}$ \\ Faculty of Social and Political Sciences, Universitas Iskandar Muda, Indonesia \\ Email: ismail.unida@gmail.com
}

\begin{abstract}
In the world of family education it is very important to foster life and encourage children to achieve learning outcomes, one of which is the economic condition of students' families. This study seeks to determine the effect of family economic background on student learning outcomes in $5^{\text {th }}$ grade student in Elementary School 2 Peukan Pidie. The approach used in this study is a quantitative approach. While the type of research used is correlation research. The population in this study were all students of $5^{\text {th }}$ grade student in Elementary School 2 Peukan Pidie in the 2019/2020 academic year, namely 33 students. The sampling technique used by the writer is purposive sampling (consideration), the writer conducts purposive sampling based on consideration and obtains $5^{\text {th }}$ grade $C$ as a research sample. Data collection techniques are done using documentation and questionnaires. Data processing uses correlation statistics and $t$-tests. The results showed that there was a significant relationship between variable $X$ (family economy) and $Y$ (student learning outcomes). The teacher makes an effort in the education of students to get the results of their learning, the parents of students' families help meet their educational needs and encourage their children to achieve good learning outcomes making students a better successor to the nation in the future.
\end{abstract}

Keywords: family economics; learning outcomes; students

\section{Introduction}

The family as the smallest unit in society is formed based on voluntary and basic love between two human subjects (husband and wife). Based on the principle of basic love, children are born as the next generation. According to Rodney Stark (in Elly M Setiadi, 2013: $301)$ is an organization or human institution contained in a society and is a kinship organizational structure that serves to socialize newborn members ". In the strict sense this family consists only of father, mother, and child. Such a family is called a nuclear family or inner family (nuclear family). In the broad sense this family covers all parties who are related by blood or offspring. Family in this sense can be called a extended family or extended family.

According to the family according to Sudiharto (2007: 24) there are two types of families, seen from the child's relationship, namely:

1. Family or biological family (family of procreation) is a family that has a blood relationship between parent and child. It can be said that this family consists of a father, mother, and biological children. Relationships in a biological family that will take place continuously. A blood relationship between parent and child cannot possibly be erased.

2. Family orientation (family of orientation) is a nuclear family which is a place for a child to obtain a protection, food, education, and so on as well as a place to orient themselves or be oriented. In this family interactions occur between parents, and biological children within the family members. In contrast to biological families, therefore in a family orientation this relationship can be severed or changed from time to time. 
A family with love and good devotion will foster and build a child's personal life. By Ki Hajar Dewantara "Efforts of parents as educators serving children". As the smallest institution in a society, so the family plays a very important role in fostering the life of a family and the life of a child's social personality, thus encouraging a child to achieve learning outcomes. Not only social status, the family economy is also very influential on children's learning habits and interests, so that it can affect children's learning outcomes.

Along with the progress and development of Science and Technology, human needs are increasing and developing. Even now education is starting to become a primary need for the community. This is in accordance with the mandate of the 1945 Constitution Article 31 paragraph 1, namely "every citizen has the right to education". So the government is obliged to strive for and organize national education because education is the most important pillar and foundation in life in order to realize the nation's bright future.

The purpose of education according to Dwi (2011: 26) "Is something to be achieved by in educational activities". Education is something that can be understood and education must begin with goals that can be assumed as values. Unknowingly goals in educational practice have no meaning. "In article 3 of Law Number 20 of 2003 concerning the National Education System, the aim of national education is to develop its potential.

Learning is a process that causes the process and the occurrence of a change or renewal in the character and behavior or ability of a person. So learning is not visible behavior. According to Djamarah (2011: 13), "Learning is a series of actions of the body and soul in order to obtain a change in behavior as a result of the experience of an individual in order to interact with their environment involving cognitive, affective and psychomotor interactions" The process of change can be achieved if influenced by several factors, namely factors from within a person or individual factors and factors from outside the individual called social factors. Individual factors themselves include maturity / growth factors, intelligence, exercise, motivation, and personal factors. Whereas social factors include family factors or household circumstances of the students themselves, the teacher and how to teach him, the tools used in teaching and learning, the environment and opportunities available, and social motivation.

The family itself is the first social institution known by the child. The family is responsible for providing financial needs for educational needs. According to Gerungan (in Kurnia Asih, 2011: 4) "the economic situation of the family certainly affects the development of children, if it is noted that with the economy that is sufficient, the material environment faced by children in the family is broader, he gets wider opportunities to develop various skills that he does not develop if there are no infrastructure. " Families with high socioeconomic conditions will not have difficulty meeting their children's school needs, in contrast to parents / families whose socioeconomic conditions are low.

The school itself accommodates students from various backgrounds or socioeconomic conditions that are heterogeneous or different. Such a situation also occurs in Elementary School 2 Peukan Pidie, where this school accommodates students from different economic backgrounds of different families. The family's economy affects the ability to finance and provide learning facilities to their children so that the socio-economic situation of the family is one of the factors that determine the success of learning in children Elementary School 2 Peukan Pidie is one of the schools in the district of Pidie that accommodates students from different socioeconomic conditions. The socioeconomic situation of the family itself can be reflected in indicators of parental education level, family income, ownership of 
home assets stairs, and meeting family needs / family expenses. Family income is the sum of the income of all family members both earned by the head of the family and other family members for a certain period of time in rupiah.

The income level of the parents of Elementary School 2 Peukan Pidie students is mostly in the middle and upper income groups, namely the high income group and the low income group. Household asset ownership is ownership of assets or wealth in the form of goods which are still beneficial in supporting the economy, the assets owned can be used to support children's education. Spending one family with another family is not the same, depending on the amount of income, the number of family members, education level and social status, and family environment.

Based on observations made by researchers, this also happened at Elementary School 2 Peukan Pidie where a student came from a low income family / poor where his interest in learning was reduced because he could not meet the facilities in education even the student liked to skip school because at night the student worked to get allowance so that it affects the learning outcomes. Due to parents' low participation or supervision of their children's school activities. Student learning activities can run as they should and as desired if the activity is supported by a variety of learning facilities and facilities that support, such as reference books, and other facilities.

These learning facilities affect the success of student learning. But what is seen in Elementary School 2 Peukan Pidie, there are students who do not have other reference books besides books given by the school in the form of student worksheets (LKS) and printed books belonging to the library. One indicator of student learning success is indicated by good student learning outcomes. The better the student learning outcomes, it can be said the student learning activities are successful. Different socioeconomic conditions of the family such as level of education, wealth owned, and meeting family needs so that in research this, want to know if there. "Relationship of Family Economic Background against Student Learning Outcomes of 5th grade student in Elementary School 2 Peukan Pidie

\section{Research Methods}

This type of research used in this study is correlation research that is a study that aims to determine the relationship or level of relationship between two or more variables. According to Arikunto, (2011: 247-248) "Correlation research is research that is intended to find out whether there is a relationship between two or more variables ". Correlation research is that the research does not require too many research subjects.

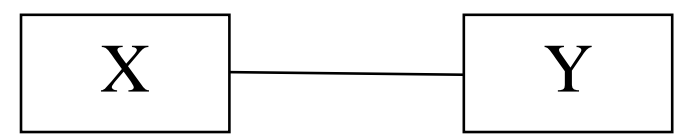

Information:

$\mathrm{X}=$ Family economy

$\mathrm{Y}=$ Student learning outcomes

This research was carried out at Elementary School 2 Peukan Pidie, which is located on Jalan Rawa - Gampong Baro, Rawa Gampong Village, Pidie Subdustrict, Pidie Regency. The research was conducted in the odd semester of the 2019/2020 school year. The population in this study were all students of Vc SD 2 Peukan Pidie in the academic year 2019/2020, namely 33 students. 
The sampling technique used by the writer is purposive sampling technique. Because in class $\mathrm{V}$ c there are parents of students whose income varies greatly and student learning facilities are inadequate. Data collection techniques used in this study were documentation and questionnaire

\section{Discussion}

Elementary School 2 Peukan Pidie is a Public Elementary School (SD) located in Aceh province with the address Jalan Rawa - Gampong Baro, Rawa Gampong Village, Kec. Pidie Kab. Pidie, Rawa, Kec. Pidie, Kab. Pidie Prov. Aceh is one of the schools in the area of Pidie Regency. SD 2 Peukan Pidie educates sons and daughters to become the next generation and heir to the nation who believe, have faith, be intelligent, and be skilled.

In accordance with the ideas expressed at the time of conducting research, the researcher prepared 33 sheets of questionnaires that had to be distributed to students of the $5^{\text {th }} \mathrm{C}$ grade student Elementary School 2 Peukan Pidie. After the questionnaire was completed, the researcher gave the opportunity to students to answer the questions given. The data collection was carried out by distributing questionnaires related to the influence of family economic background on student learning outcomes. The questions given consisted of 20 questions relating to the family economy. Each question given has a maximum score of 1 . So, the highest score that can be achieved by students is 100 and the lowest score is 20 . The results of the study are tabulated in the form of the following table:

Table 1. Income table for parents of students in class V c

\begin{tabular}{|c|c|c|c|c|c|c|}
\hline \multirow{2}{*}{ No } & \multirow{2}{*}{ Student name } & \multicolumn{2}{|c|}{ Parents income } & \multicolumn{2}{|c|}{ Accretion } & \multirow{2}{*}{ Total } \\
\cline { 3 - 6 } & & Father & Mother & Father & Mother & \\
\hline & Student 1 & 2.500 .00 & 2.500 .000 & 1.000 .000 & 500.000 & 6.500 .000 \\
\hline 2 & Student 2 & - & 1.000 .000 & - & 200.000 & 1.200 .000 \\
\hline 3 & Student 3 & - & 1.000 .000 & - & - & 1.000 .000 \\
\hline 4 & Student 4 & 1.500 .000 & - & - & - & 1.500 .000 \\
\hline 5 & Student 5 & 5.000 .000 & - & 2.000 .000 & - & 7.000 .000 \\
\hline 6 & Student 6 & 4.000 .000 & - & 1.000 .000 & - & 5.000 .000 \\
\hline 7 & Student 7 & 1.000 .000 & - & - & - & 1.000 .000 \\
\hline 8 & Student 8 & 2.500 .000 & - & 500.000 & - & 3.000 .000 \\
\hline 9 & Student 9 & 4.000 .000 & 2.500 .000 & - & - & 6.500 .000 \\
\hline 10 & Student 10 & 10.000 .000 & 3.000 .000 & 5.000 .000 & 1.000 .000 & 19.000 .000 \\
\hline 11 & Student 11 & 1.500 .000 & - & 500.000 & - & 2.000 .000 \\
\hline 12 & Student 12 & 1.650 .000 & - & - & - & 1.650 .000 \\
\hline 13 & Student 13 & 500.000 & - & 200.000 & - & 700.000 \\
\hline 14 & Student 14 & - & 1.000 .000 & - & 300.000 & 1.300 .000 \\
\hline 15 & Student 15 & 4.000 .000 & - & 2.000 .000 & - & 6.000 .000 \\
\hline 16 & Student 16 & 4.000 .000 & - & - & - & 4.000 .000 \\
\hline 17 & Student 17 & - & 1.500 .000 & - & - & 1.500 .000 \\
\hline 18 & Student 18 & 5.000 .000 & - & 2.000 .000 & - & 7.000 .000 \\
\hline 19 & Student 19 & 7.000 .000 & - & - & - & 7.000 .000 \\
\hline 20 & Student 20 & 10.000 .000 & - & - & - & 10.000 .000 \\
\hline 21 & Student 21 & 2.500 .000 & 2.000 .000 & - & 1.000 .000 & 3.500 .000 \\
\hline 22 & Student 22 & 1.500 .000 & - & 500.000 & - & 2.000 .000 \\
\hline 23 & Student 23 & 4.000 .000 & 2.500 .000 & 1.000 .000 & 500.000 & 8.000 .000 \\
\hline 24 & Student 24 & 1.650 .000 & - & 500.000 & - & 2.500 .000 \\
\hline
\end{tabular}




\begin{tabular}{|l|c|c|c|c|c|c|}
\hline 25 & Student 25 & 1.500 .000 & - & 200.000 & - & 1.700 .000 \\
\hline 26 & Student 26 & 2.500 .000 & - & 500.000 & - & 3.000 .000 \\
\hline 27 & Student 27 & 4.000 .000 & - & 1.000 .000 & - & 5.000 .000 \\
\hline 28 & Student 28 & 5.000 .000 & 2.500 .000 & - & 1.000 .000 & 8.500 .000 \\
\hline 29 & Student 29 & 2.500 .000 & - & 1.000 .000 & - & 3.500 .000 \\
\hline 30 & Student 30 & 1.500 .000 & - & 200.000 & - & 1.700 .000 \\
\hline 31 & Student 31 & 4.000 .000 & 2.500 .000 & - & 1.000 .000 & 7.500 .000 \\
\hline 32 & Student 32 & 4.000 .000 & 2.500 .000 & - & 1.000 .000 & 7.500 .000 \\
\hline 33 & Student 33 & 2.000 .000 & 2.500 .000 & - & 1.000 .000 & 5.500 .000 \\
\hline
\end{tabular}

Table 2. Parents' Occupation

\begin{tabular}{|l|l|l|l|}
\hline \multicolumn{4}{|c|}{ Parents' Occupation } \\
\hline Father & Total & Mother & Total \\
\hline Civil servants & 10 Persons & Civil servants & 7 Persons \\
\hline Seller & 8 Persons & Seller & 1 Persons \\
\hline entrepreneur & 9 Persons & entrepreneur & 1 Persons \\
\hline Sailor & 1 Persons & Sailor & 20 Persons \\
\hline
\end{tabular}

Table 3. Student learning outcomes in school (Y)

\begin{tabular}{|c|lc|c|}
\hline No & \multicolumn{2}{|l|}{ Studens' Name } & Students' Result \\
\hline 1 & Student & 1 & 85 \\
\hline 2 & Student & 2 & 86 \\
\hline 3 & Student & 3 & 86 \\
\hline 4 & Student & 4 & 86 \\
\hline 5 & Student & 5 & 87 \\
\hline 6 & Student & 6 & 89 \\
\hline 7 & Student & 7 & 90 \\
\hline 8 & Student & 8 & 87 \\
\hline 9 & Student & 9 & 87 \\
\hline 10 & Student & 10 & 92 \\
\hline 11 & Student & 11 & 88 \\
\hline 12 & Student & 12 & 89 \\
\hline 13 & Student & 13 & 84 \\
\hline 14 & Student & 14 & 87 \\
\hline 15 & Student & 15 & 85 \\
\hline 16 & Student & 16 & 82 \\
\hline 17 & Student & 17 & 85 \\
\hline 18 & Student & 18 & 82 \\
\hline 19 & Student & 19 & 83 \\
\hline 20 & Student & 20 & 91 \\
\hline 21 & Student & 21 & 86 \\
\hline 22 & Student & 22 & 90 \\
\hline 23 & Student & 23 & 89 \\
\hline 24 & Student & 24 & 84 \\
\hline 25 & Student & 25 & 85 \\
\hline 26 & Student & 26 & 89 \\
\hline 27 & Student & 27 & 87 \\
\hline 28 & Student & 28 & 94 \\
\hline 29 & Student & 29 & 94 \\
\hline & & & \\
\hline
\end{tabular}




\begin{tabular}{|c|lc|c|}
\hline 30 & Student & 30 & 88 \\
\hline 31 & Student & 31 & 85 \\
\hline 32 & Student & 32 & 85 \\
\hline 33 & Student & 33 & 91 \\
\hline & Total & 2878 \\
\hline
\end{tabular}

After tabulating data related to student achievement in school, the researcher tabulated the independent variables, namely the family economy and is described in the study as follows.

Table 4. Results of the family economic questionnaire (x)

\begin{tabular}{|l|ll|c|}
\hline No & Students' Code & Questionnaire Score \\
\hline 1 & Student & 1 & 69 \\
\hline 2 & Student & 2 & 58 \\
\hline 3 & Student & 3 & 56 \\
\hline 4 & Student & 4 & 55 \\
\hline 5 & Student & 5 & 56 \\
\hline 6 & Student & 6 & 55 \\
\hline 7 & Student & 7 & 61 \\
\hline 8 & Student & 8 & 66 \\
\hline 9 & Student & 9 & 73 \\
\hline 10 & Student & 10 & 71 \\
\hline 11 & Student & 11 & 49 \\
\hline 12 & Student & 12 & 54 \\
\hline 13 & Student & 13 & 79 \\
\hline 14 & Student & 14 & 70 \\
\hline 15 & Student & 15 & 51 \\
\hline 16 & Student & 16 & 46 \\
\hline 17 & Student & 17 & 49 \\
\hline 18 & Student & 18 & 48 \\
\hline 19 & Student & 19 & 56 \\
\hline 20 & Student & 20 & 57 \\
\hline 21 & Student & 21 & 61 \\
\hline 22 & Student & 22 & 55 \\
\hline 23 & Student & 23 & 47 \\
\hline 24 & Student & 24 & 53 \\
\hline 25 & Student & 25 & 87 \\
\hline 26 & Student & 26 & 75 \\
\hline 27 & Student & 27 & 61 \\
\hline 28 & Student & 28 & 72 \\
\hline 29 & Student & 29 & 65 \\
\hline 30 & Student & 30 & 71 \\
\hline 31 & Student & 31 & \\
\hline 32 & Student & 32 & 33 \\
\hline 33 & Student & 33 & \\
\hline & Total & & 599 \\
\hline & & & \\
\hline
\end{tabular}

Based on data about the two variables above, the next step is to perform data processing to determine the relationship between the two variables. The steps that the writer must take are:

1. Determine the value of squared X (family economy)

2. Determine the total value of squared $X$ (family economy) 
3. Determine the value of Quadratic Y (student learning outcomes)

4. Determine the total value of $Y$ squared (Student learning outcomes)

5. Determine the number of multiplications between variables $\mathrm{X}$ (family economy) and $\mathrm{Y}$ (student learning outcomes)

6. Determine the total value of multiplication between variables $\mathrm{X}$ (family economy) and $\mathrm{Y}$ (learning outcomes)

Table 5. Analysis of the Relationship between the $\mathrm{Y}$ variable (student learning outcomes) and $\mathrm{X}$ (family economics)

\begin{tabular}{|c|c|c|c|c|c|c|c|}
\hline \multirow{2}{*}{ No } & \multirow{2}{*}{\multicolumn{2}{|c|}{ Students' Name }} & \multicolumn{5}{|c|}{ Score } \\
\hline & & & $X$ & $\mathrm{Y}$ & $\mathrm{X} 2$ & y2 & $\mathrm{Xy}$ \\
\hline 1 & Student & 1 & 85 & 69 & 7225 & 4761 & 5865 \\
\hline 2 & Student & 2 & 86 & 58 & 7396 & 3364 & 4988 \\
\hline 3 & Student & 3 & 86 & 56 & 7396 & 3136 & 4816 \\
\hline 4 & Student & 4 & 86 & 55 & 7396 & 3025 & 4730 \\
\hline 5 & Student & 5 & 87 & 56 & 7569 & 3136 & 4872 \\
\hline 6 & Student & 6 & 89 & 55 & 7921 & 3025 & 4895 \\
\hline 7 & Student & 7 & 90 & 61 & 8100 & 3721 & 5490 \\
\hline 8 & Student & 8 & 87 & 66 & 7569 & 4356 & 5742 \\
\hline 9 & Student & 9 & 87 & 73 & 7569 & 5329 & 6351 \\
\hline 10 & Student & 10 & 92 & 71 & 8464 & 5041 & 6532 \\
\hline 11 & Student & 11 & 88 & 49 & 7744 & 2401 & 4312 \\
\hline 12 & Student & 12 & 89 & 54 & 7921 & 2916 & 4806 \\
\hline 13 & Student & 13 & 84 & 79 & 7056 & 6241 & 6636 \\
\hline 14 & Student & 14 & 87 & 70 & 7569 & 4900 & 6090 \\
\hline 15 & Student & 15 & 85 & 51 & 7225 & 2601 & 4335 \\
\hline 16 & Student & 16 & 82 & 46 & 6724 & 2116 & 3772 \\
\hline 17 & Student & 17 & 85 & 49 & 7225 & 2401 & 4165 \\
\hline 18 & Student & 18 & 82 & 48 & 6724 & 2304 & 3936 \\
\hline 19 & Student & 19 & 83 & 56 & 6889 & 3136 & 4648 \\
\hline 20 & Student & 20 & 91 & 57 & 8281 & 3249 & 5187 \\
\hline 21 & Student & 21 & 86 & 61 & 7396 & 3721 & 5246 \\
\hline 22 & Student & 22 & 90 & 55 & 8100 & 3025 & 4950 \\
\hline 23 & Student & 23 & 89 & 47 & 7921 & 2209 & 4183 \\
\hline 24 & Student & 24 & 84 & 53 & 7056 & 2809 & 4452 \\
\hline 25 & Student & 25 & 85 & 87 & 7225 & 7569 & 7395 \\
\hline 26 & Student & 26 & 89 & 75 & 7921 & 5625 & 6675 \\
\hline 27 & Student & 27 & 87 & 61 & 7569 & 3721 & 5307 \\
\hline 28 & Student & 28 & 94 & 72 & 8836 & 5184 & 6768 \\
\hline 29 & Student & 29 & 94 & 65 & 8836 & 4225 & 6110 \\
\hline 30 & Student & 30 & 88 & 64 & 7744 & 4096 & 5632 \\
\hline
\end{tabular}




\begin{tabular}{|l|lc|c|c|c|c|c|}
\hline 31 & Student & 31 & 85 & 58 & 7225 & 3364 & 4930 \\
\hline 32 & Student & 32 & 85 & 51 & 7225 & 2601 & 4335 \\
\hline 33 & Student & 33 & 91 & 71 & 8281 & 5041 & 6461 \\
\hline & Total & & 2878 & 1999 & 251298 & 124349 & 174612 \\
\hline
\end{tabular}

To prove the strength of the relationship between the two variables and the acceptance or rejection of the hypothesis proposed in this thesis, it will be proven by finding the correlation coefficient between variables X (family economy) with Y (student learning outcomes). The author uses the product moment correlation formula as follows:

$r_{x y}=\frac{N \sum X Y-\left(\sum X\right)\left(\sum Y\right)}{\sqrt{\left\{N \sum X^{2}-\left(\sum X^{2}\right)\right\}\left\{N \sum Y^{2}-\left(\sum Y^{2}\right)\right\}}}$

Based on the results of the analysis above, the correlation value between variable $\mathrm{X}$ (family economy) and $\mathrm{Y}$ variable (learning outcomes) is obtained that the correlation value is 0.14. Furthermore, the authors determine the relationship between the two correlations by referring to the provisions table set by Arikunto (2006:189) as follows:

$$
\begin{aligned}
\mathrm{R}_{\mathrm{xy}} & =\frac{N \sum X Y-\left(\sum X\right)\left(\sum Y\right)}{\sqrt{\left(N \sum X^{2}-\left(\sum X^{2}\right)\right\}\left[N \sum Y^{2}-\left(\sum Y^{2}\right)\right\}}} \\
& =33 \times 174612-(2878)(1999) \\
& =\frac{33 \times 174612-(2878)(1999)}{\sqrt{\{(33 \times 251298-(2878) 2\}\{33 \times 124349-(1999) 2)}} \sqrt{\{(8292834-8282884)(4103517-3996001)\}} \\
& =\frac{9074}{\sqrt{(9950)(107516)}} \\
& =\frac{9074}{\sqrt{1069784}}=\frac{9074}{103431}=0,88
\end{aligned}
$$

Based on the results of the analysis above, the correlation value between $\mathrm{X}$ (family economics) and $\mathrm{Y}$ (student learning outcomes) is obtained that the correlation value is 0.88 then the author determines the relationship between the two correlations by referring to the provisions table set by Arikunto (2011: 189) as follows:

Table 6. Correlation Value Criteria

\begin{tabular}{|c|l|}
\hline $\begin{array}{c}\text { The amount of "r" } \\
\text { Product Moment (rxy) }\end{array}$ & \multicolumn{1}{|c|}{ Interpretation } \\
\hline $0,00-0,19$ & $\begin{array}{l}\text { Between the variables X1 and X2 against the Y } \\
\text { variable there is indeed a correlation, it is very weak, } \\
\text { the order is so low that the correlation is ignored (it is } \\
\text { assumed there is no correlation between the variables } \\
\mathrm{X} \text { and } \mathrm{Y} \text { ) } \\
\text { Between variables X1 and X2 with variable Y there is a } \\
\text { weak or low correlation } \\
\text { Between variables X1 and X2 against Y there is a } \\
\text { moderate or sufficient correlation }\end{array}$ \\
$0,20-0,39$ & \multicolumn{2}{|c|}{$\mid$} \\
\hline
\end{tabular}




\begin{tabular}{|l|l|}
\hline $0,70-0,89$ & $\begin{array}{l}\text { Between the variables } \mathrm{X} 1 \text { and } \mathrm{X} 2 \text { against the } \mathrm{Y} \\
\text { variable there is a sufficient or high correlation } \\
\text { Between variables X1 and } \mathrm{X} 2 \text { against } \mathrm{Y} \text { there is a very } \\
\text { strong or very high correlation }\end{array}$ \\
\hline
\end{tabular}

Based on the results of data processing above, obtained a rxy value of 0.88 , this shows that between the variable $\mathrm{X}$ (family economy) against the variable $\mathrm{Y}$ (student learning outcomes) has a sufficient or high correlation. Thus it can be seen that there is a sufficient or high relationship between $\mathrm{X}$ (family economy) on the variable $\mathrm{Y}$ (student learning outcomes). Furthermore, the authors determine the value of $\mathrm{t}$ arithmetic for hypothesis testing based on the formula as follows:

$$
\begin{aligned}
& t=\frac{r \sqrt{ } n-2}{1-\sqrt{r 2}} \\
& =\frac{0,88 \sqrt{33-2}}{1-0,88^{2}} \\
& =\frac{0,88(6)}{0,23} \\
& =\frac{5,28}{0,23}=22,95
\end{aligned}
$$

In this study the authors used a 95\% confidence level so that the level of significance or error rate 0 of $5 \%(0.05)$ and using $\mathrm{dk}=\mathrm{n}-2$

$\mathrm{dk}=(33-2)=1,684$ while the provisions for hypothesis testing are:

From the distribution list the values $\mathrm{dk}$ (33) and t-table 1.684 are obtained because $\mathrm{t}$ table $\mathrm{t}$-count $>\mathrm{t}$-table or $1.75>1.684$, then the alternative hypothesis is accepted. Thus the hypothesis that reads "there is a significant relationship between economic conditions of the family with student learning outcomes.

The economic condition of the family is very important for students to complete the facilities for the needs of school students, the results of the above data processing, obtained a rxy value of 0.88 . Thus it can be seen that there is a sufficient or high relationship. Between $\mathrm{X}$ (Family Economy) to Y (Student learning outcomes). T-arithmetic analysis showed that the tvalue of 22.95 and t-table 1.684, because $t$-count $>t$-table or $22.95>1.686$, then the alternative hypothesis was accepted. Thus the hypothesis that reads "there is a synergic relationship between the family economy and student learning outcomes.

Achieving learning outcomes not only from schools or teachers who play an important role in it, the economic condition of the family is important in achieving better learning outcomes. Pay close attention that with sufficient parents' economic conditions the material environment faced by the child in his family will not be wider, he will have a better chance of developing various skills that cannot be developed if he does not have the infrastructure. "If a child lives in a poor family, a child's basic needs are not met, so that the child's health and education will be disrupted and the child's learning will be disrupted. Another consequence that can be seen is that a child is always afflicted with sadness so that the child feels inferior to his other friends.

According to Patmonodewo (2011: 37) "there is a very significant difference in intellectual and academic tasks between children who come from underprivileged families 
compared to children who are more economically capable." be a whip for a child to learn more actively in learning and trying.

Learning activities are an inseparable part of all their activities in studying at formal educational institutions. According to Dimyati and Mudjiono (2013: 7) "learning is a complex action and behavior. As an action, learning is only experienced by students themselves, students are determinants of the occurrence or not of the learning process". According to Sardiman, AM, (2014: 23) "learning is a change in behavior, and occurs because of the results of experience". In line with that Iskandar (2012: 102) said "learning is an attempt by a person through interaction with his environment to change his behavior". According to Kurniawan (2014: 4) said "learning as an internal active process of individual students where through various experiences in interacting with the environment causes a change in behavior that is relatively permanent".

Learning outcomes are measurements of the assessment of learning activities or learning processes expressed in the form of symbols, letters and sentences that tell the results that have been achieved by each student in a certain period. According to Susanto (2013: 5) "Learning outcomes are changes that occur in individual students, both relating to cognitive aspects, affective aspects, and psychomotor aspects as a result of learning". The understanding of learning outcomes is emphasized by Nawawi (in Susanto, 2013: 5) states that "learning outcomes can be expressed as the level of success of students in learning material and concept of learning in school that can be seen in the scores or scores obtained from test results from a number of subject matter certain".

From the above explanation it can be concluded that learning activities are a very important and inseparable part of all the activities that they do in their studies at formal educational institutions. Every family needs to encourage their children to get good learning outcomes by meeting their children's needs or needs in studying. Economics is very important in every family in meeting their children's needs in education, parents need to provide school equipment for their children from the smallest to the largest, so that their children can achieve better achievement or learning outcomes.

\section{Conclusion}

Based on the results of previous data processing, it shows that the value of $\mathrm{r}$ is 0.88 , the value of $\mathrm{t}$-count is 22.95 while the $\mathrm{t}$-table is 1,684 , thus $\mathrm{t}$-count $>$ of $\mathrm{t}$-table so there is a significant relationship between variable $\mathrm{X}$ (family economy) to $\mathrm{Y}$ (student learning outcomes), it can be concluded that there is a relationship between the family's economic background to student learning outcomes at Elementary School 2 Peukan Pidie. With a good family economy, parents can meet the needs of their children in studying in various formal educational places so that students can achieve learning goals and achieve good learning outcomes. Making students as children who are proud of parents, schools and the nation's homeland.

The suggestions to be conveyed in this researcher are as follows:

1. Based on the socioeconomic conditions of the families of students of Elementary School 2 Peukan Pidie, it is expected that the student's family can manage its finances so that family expenses do not exceed the income received and prioritize meeting the educational needs of children. 
2. Improving student learning outcomes can also be done by parents, namely by providing private (tutoring), with the tutoring students can learn or repeat learning in their schools. Learning to get good grades is not only done at school or at other formal places.

3. Improvement of student learning outcomes in schools. Harmonious relationships must also be established between parents and children. In addition, if necessary parents can include children in the AMT (Achievement Motivation Training), which is a personal development program, especially in terms of improving learning outcomes.

4. The researchers are expected to examine the effect of family economic background on student learning outcomes with other variables, thus providing new knowledge to various parties.

\section{References}

Abudullah, Ma'ruf. (2015). Metodelogi penelitian kuantitatif (Untuk: Ekonomi, Manajemen, Komunikasi, dan Soaial lainnya). Yogyakart: Aswaja Pressindo.

Ahmad, Firdaus. (2009). Akuntansi BiayaEdisi 2. Jakarta: Alfabeta

A.M. Sardiman. (2011). Interaksi dan Motivasi Belajar Mengajar. Jakarta: PT Raja grafindo.

A.M, Sardiman. (2014). Interaksi dan Motivasi Belajar Mengajar. Jakarta: Rajawali Pers.

Ahmad, Susanto. (2013). Teori Belajar dan Pembelajaran di Sekolah Dasar. Jakarta: Kencana Prenada Media Group.

Arikunto. (2011).Prosedur Penelitian suatu Pendekatan Praktik . Jakarta: Rineka Cipta.

Agus Suprijono. (2013). Cooperative Learning Teori dan Aplikasi PAIKEM.Yogyakarta: Pusaka Pelajar.

Agung, Iskandar. (2012). Panduan Penelitian Tindakan Kelas Bagi Guru. Jakarta: Bestari Buana Murni.]

Agung, kurniawan. (2014). Belajar dan pembelajaran. Jakarta: Mitra Wacana Media

Bahri Djamarah, S. (2011). Psikologi Belajar. Jakarta: PT. Rineka Cipta.

Budiningsih, Asri. (2013). Belajar dan Pembelajaran. Jakarta: PT. Rineka Cipta.

Daryanto, H.M. (2006). Administrasi Pendidikan. Jakarta: PT Rineka Cipta

Daradjat, Zakiah. (2008). Fasilitas belajar dan Macam-Macam Jenis Belajar. Bandung: Alfabeta

Dimyati dan Mudjiono. (2013). Belajar dan Pembelajaran. Jakarta: PT Rineka Cipta

Gerungan, W.A. (2011).Psikologi Sosial. Bandung: PT. Refika aditama,

Hamalik, Oemar. (2011). Kurikulumdan Pembelajaran.Jakarta: Bumi Aksara.

http://www.pendidikanekonomi.com/2012/05/defenisi-ilmu-ekonomi-oleh-prof-p.html

Iskandar Putong. (2013). EconomicsPengantar Mikro dan Makro . Jakarta: Mitra Wacana Media.

Jihad, Asep dan Abdul Haris. (2012). Evaluasi Pembelajaran. Yogyakarta: Multi Presindo

M. Ngalim Purwanto. (2011). Psikologi Pendidikan. Bandung: Remadja Karya.

Margono. (2011). Metode Penrlitian Kuantitatif. Jakarta: Grapido

Mankiw N,Gregory. (2013). Pengantar Ekonomi Makro. Jakarta: Salemba Empa

MN, Nasution. (2005). Manajemen Mutu Terpadu (Total Quality Management). Jakarta: Ghalia Indonesia.

Nasution dan Nashori. (2012). Harga Diri Anak Jalanan. Karya Ilmiah: UII

Purwanto, Ngalim. (2011). Psikologi Pendidikan.Bandung: PT Remaja Rosdakarya Offset.

Purwati. (2011). Ilmu Sosial Ekonomi. Jakarta: Indeks.

Patmonodewo, Soemiarti. (2011). Pendidikan Anak Prasekolah. Jakarta: Rineka Cipta

Rusman. (2015). PembelajaranTematik Terpadu (Teori, Praktik, Penilaian). Jakarta: Rajawali Pres.

Riwanto. (2012). Faktor Pengukuran Ekonomi Keluarga. Jakarta: Mitra Wacana Media.

Rifai. (2012). Psikologi Pendidikan. Semarang: UNNES Press

Rusman. (2012).Model-Model Pembelajaran.Depok : PT Rajagrafindo Persada. 
Roestiyah N.K. (2012).Masalah Pengajaran Sebagai Suatu System. Jakarta:Rineka Cipta

Syaifudin Zuhri. (2011). Pengaruub Tingkat Ekonomi Orang Tua Terhadap Motivasi Belajar Siswa MTsN Nurul Huda Tarub Grobogan Tahun Ajaran 2010-2011.Skripsi tidak diterbitkan.Semarang : Fakultas Tarbiyah IAIN Walisongo.

Sardiman. (2011).Interaksidan Motivasi Belajar Mengajar. Jakarta: PT Raja Grafindo Persada Sagala, Syaiful. (2010). Konsep dan Makna Pembelajaran. Bandung: Alfabeta.

Syah, Muhibbin. (2011). Psikologi Belajar. Jakarta: Logos Wacana Ilmu.

Setiadi, Elly M. (2011). Pengantar Sosiologi. Jakarta: Kencana Preneda Media Group

Sudiharto. (2007).Asuhan Keperawatan keluarga dengan pendekatan keperawatan transkultural Jakarta : EGC

Samino, Saring Marsudi. (2011). Layanan Bimbingan Belajar. Fairuz Media: Surakarta.

Slameto. (2013). Belajar dan Faktor-faktor yang mempengaruhinya. Jakarta : Rimeka Cipta.

Slameto. (2003). Fasilitas Belajar. Bandung: Tarsito.

Sugiyono. (2012).Metode Penelitian Kuantitatif Kualitatif Dan R\&D. Bandung : Alfabeta

Sugiyono. (2015).Metode Penelitian Pendidikan Pendekatan Kuantitatif, Kualitatif, dan R\&D.Bandung: Alfabeta

Sugiyono. (2013). Metode dan Tekhnik Menyusun Proposal. Bandung : Alfabeta

Sugiyono. (2011). Tekhnik Pengolahan Data. Jakarta: Bima Aksara

Siswoyo, Dwi et al. (2011). Ilmu Pendidikan. Yogyakarta: UNY Press

Samuelson, PA. (2013). Ilmu Makroekonomi. Jakarta: PT. Media Global Edukasi.

Samuelson, PA. (2012). Kebutuhan Primer Sekunder dan Tersier. Jakarta: PT. Media Global Edukasi.

Sukirno, Sadono. (2013). Teori Mikro Ekonomi. Jakarta: Rajawali Press

Soekanto, Soerjono. (2011). Sosiologi suatu Pengantar. Jakarta: P.T.Raja Grafindo.

Sumardi, M. (2011). Kemiskinan dan Kebutuhan Pokok. Jakarta: Raja wali.

Siagian, Sondang. (2012). Manajemen Sumber Daya Manusia. Jakarta: Bumi Aksara.

Yuli Astuti,Wurdiyanti. (2016).Pengaruh Kondisi Sosial Ekonomi Keluarga Terhadap Minat Belajar Siswa SMK YPKK 3 Sleman.Jogjakarta : Skripsi FE UNY 